\title{
ADIPOSE TISSUE AND CARDIOVASCULAR AND METABOLIC DISEASES
}

\author{
Alison M. Coates \\ ATN Centre for Metabolic Fitness and Nutritional Physiology Research Centre, School of Health \\ Sciences, University of South Australia, Adelaide, South Australia, Australia
}

Obesity is a major contributor to the rising prevalence of cardiovascular and metabolic diseases in both the developed and developing world. Increased adipose tissue mass is associated with changes to the structure and function of the cardiovascular system to ensure circulatory requirements are met. Adipose tissue is a metabolically active endocrine organ that is capable of synthesizing and releasing a variety of signal proteins (adipokines), many of which impact unfavorably on both the cardiovascular system and metabolism. The extent of adiposity, location of fat deposits and variations in the secretion of adipokines, along with other factors, determine whether a particular obese person develops complications, including type 2 diabetes, coronary artery disease, congestive heart failure, hypertension, obstructive sleep apnea syndrome, and non-alcoholic fatty liver disease. This review will discuss the relationship between obesity and cardiovascular and metabolic diseases and will explore how complications of obesity impact on mortality, while healthy lifestyle may prevent them. Biomed Rev 2006; 17: 89-104.

Key words: adipokines, dyslipedmia, hypertension, metabolic syndrome, non-alcoholic fatty liver disease, obstructive sleep apnea syndrome

\section{INTRODUCTION}

Obesity is a chronic condition characterized by the accumulation of excess fat, to the extent that health may be adversely affected (1). It is a multifactorial disorder that develops via interaction between genetics and environment $(2,3)$. In the modern western world, it is very easy to access large volumes of energy-dense foods at low cost and with minimal energy expended. When energy intake is greater than energy expenditure, adipose tissue increases. With excess body weight comes the risk of long-term health consequences. Presently, all overweight and obese adults aged $>18$ years and with a body mass index $(\mathrm{BMI}) \geq 25 \mathrm{~kg} / \mathrm{m}^{2}$ are considered at risk for developing one or more of the many comorbidities associated with obesity, such as hypertension, dyslipidemia, type 2 diabetes mellitus (T2DM), coronary heart disease (CHD), gallbladder disease, non-alcoholic fatty liver disease (NAFLD), stroke, osteoporosis, obstructive sleep apnea, polycystic ovary syndrome, and some types of cancers (1).

This review will address these complications and the associations between cardiovascular disease (CVD) and obesity and the impact of excess body weight on overall morbidity

Received 1 November 2006, received revised 27 November 2006, accepted 29 November 2006.

Correspondence and reprint request to Dr Alison Coates, Nutritional Physiology Research Centre, School of Health Sciences, University of South Australia, BJ1-71 City East Campus, Adelaide, SA 5001 Australia. Tel.: 61883022313 ,

Fax: 6188302 2178, Email:alison.coates@unisa.edu.au 


\section{List of Abbreviations}

$\begin{aligned} \text { BMI } & \text { Body mass index } \\ \text { BP } & \text { Blood pressure } \\ \text { CAD } & \text { Coronary artery disease } \\ \text { CHD } & \text { Coronary heart disease } \\ \text { CHF } & \text { Chronic heart failure } \\ \text { CO } & \text { Cardiac output } \\ \text { CVD } & \text { Cardiovascular disease } \\ \text { DBP } & \text { Diastolic blood pressure } \\ \text { HDL } & \text { High-density lipoprotein } \\ \text { HRR } & \text { Heart rate recovery } \\ \text { IL-1 } & \text { Interleukin-1 } \\ \text { IMT } & \text { Intimal-medial thickness } \\ \text { LVM } & \text { Left ventricular mass } \\ \text { MCP-1 (CCL2) } & \text { Monocyte chemoattractant protein 1; } \\ & \text { cysteine-cysteine motif chemokine ligand } 2\end{aligned}$

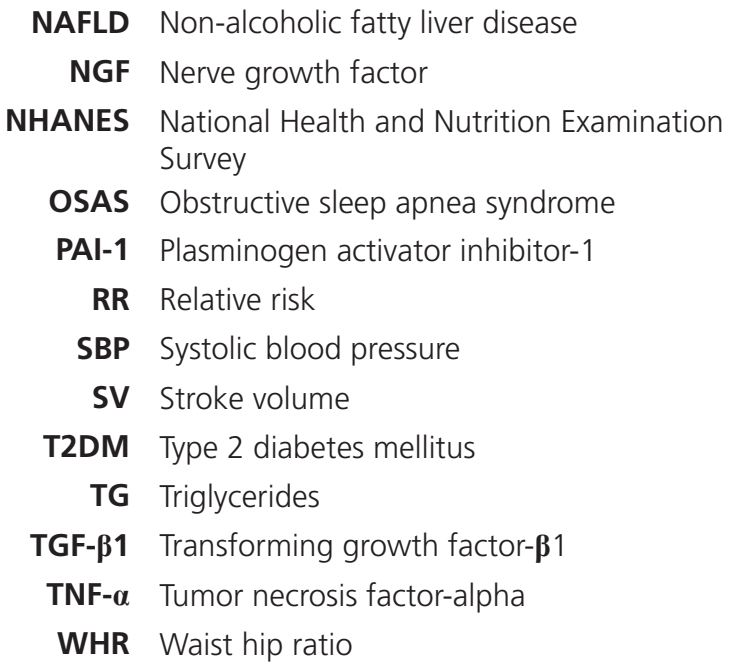

and mortality (4), such that life expectancy is greatly reduced in obesity (5).

\section{PREVALENCE OF OBESITY}

The latest report from The Centers for Disease Control and Prevention in the United States shows the prevalence of obesity continues to increase (6). In 1991, four States had obesity prevalence rates of 15-19\% and no States had rates at or above $20 \%$. Over the past 15 years, there has been a steady increase, such that in 2005 only 4 States had obesity prevalence rates less than $20 \%$, while 17 States had prevalence rates equal to or greater than 25 percent, with 3 of those having prevalence equal to or greater than $30 \%$. This trend is being observed in other developed and developing countries in adults (1, 7-9), children and adolescents (10-13). The Aus-Diab study reported that the prevalence of obesity in Australian adults was 2.5 times higher in the year 2000 than in 1980 (9). A large cohort study of over 64,000 Finnish adolescents reported that the prevalence of overweight increased from 7.2 to $16.7 \%$ in boys and from 4.0 to $9.8 \%$, in girls between 1977 and 1999, while the prevalence of obesity increased 3 fold (13).

\section{Impact of obesity on the prevalence of cardiovascular disease-related mortality}

While the incidence of obesity has expanded dramatically in the past 2 decades, so has the number of deaths associated with the condition. Data from five large prospective cohort studies have been used to calculate the annual number of deaths at- tributable to obesity in adults in 1991 (14). The authors found that $80 \%$ of deaths attributable to obesity occurred in people with a BMI $>30 \mathrm{~kg} / \mathrm{m}^{2}$. However, a number of limitations are encountered in this meta-analysis. Data were collected from a predominantly Caucasian population, half of the studies included self-reported body weight data, the statistical analysis model considered only age, smoking and sex and the outcomes were not assessed after 1991. Flegal et al (15) reported that the relative risk of mortality associated with obesity with a BMI > $35 \mathrm{~kg} / \mathrm{m}^{2}$ was twice that of a healthy weight individual, with influence diminishing in the elderly (age $>70$ years). Of note, mortality related to obesity has declined since the first National Health and Nutrition Examination Survey (NHANES) study in 1971 (15), a result most likely due to a more aggressive approach to the treatment of associated CVD risk factors in obese patients.

In a recent analysis by Yan et al, baseline measurements of BMI were recorded before the age of 65 years in 17,643 subjects from the Chicago Heart Study, free of CHD and diabetes (16). The outcome of death from CHD, CVD or diabetes after the age of 65 years was adjusted for hypertension, hypercholesterolemia and cigarette smoking. At a low level of risk, obesity had very little impact on CVD outcomes but did impact on the relative risk of diabetes, but for obese subjects at moderate risk there was a two-fold increased risk of CHD mortality and a 5-fold increase risk for diabetes. Overall, these data suggest that obese subjects during midlife have a greater likelihood of mortality from CHD after the age of 65 years, 
independent of the presence of hypertension, hypercholesterolemia and cigarette smoking.

\section{Age of onset of obesity: what are the implications for morbidity and mortality?}

Early-onset obesity in children is also a risk factor for morbidity and mortality later in life $(17,18)$ and approximately $70 \%$ of obese adolescents grow up to become obese adults (19). Although the persistence of excess adiposity from childhood to adulthood is a morbidity risk factor, it is unclear whether total body fat or body fat distribution is the main factor responsible (18). Obesity is also associated with the metabolic syndrome in adolescents (20). The SEARCH for Diabetes in Youth Study (a multicentred trial conducted across 6 States of the USA) reported that children and adolescents with diabetes may be at significant increased risk of premature CVD, since the prevalence of multiple CVD risk factors was high among children and adolescents with diabetes, including children as young as 3 years (21). If elevated blood pressure (BP) is also present in childhood or adolescent obesity then there is an increased risk of hypertension in adulthood, with central adiposity influencing the extent of elevation (22). However, the way in which obesity is determined impacts on whether there is an association between obesity in early life and tracking into adulthood. Wright et al (23) reported on 412 members of the thousand families 1947 birth cohort, from Newcastle in the UK. They found an association between BMI at age 9, 13 and 50 such that those who had been above the $90^{\text {th }}$ percentile for BMI at age 9 or 13 years were between five and nine times more likely to be obese (BMI $>30$ ) as adults (age 50) when compared with those in the thinnest quartile in childhood. However, when percent body fat was measured at age 50 using bioelectrical impedance, the association with BMI in childhood was no longer significant. Another important finding from this study was that those who were thin in childhood and adolescence were not protected from obesity as adults, which is an important public health message.

\section{CARDIORESPIRATORY FITNESS AND CARDIOVASCULAR RISKS}

An important parameter often overlooked in outcome studies in overweight and obese subjects is the level of physical activity. Low levels of fitness are associated with an increased prevalence of CVD risk factors (24) and the level of physical activity is a predictor of CHD, independent of the presence of obesity
(25). Previous findings suggest that even light-to-moderate activity is associated with lower CHD rates in women, with as little as 1 hour of walking per week associated with a reduction in risk. It was encouraging to note from this study that the intensity of exercise did not dictate the benefit gained (26). In women with established CHD, higher self-reported physical fitness scores were independently associated with fewer risk factors for coronary artery disease (CAD), less angiographic $\mathrm{CAD}$, and lower risk for adverse cardiovascular events (27). These studies promote an increase in physical activity for cardiovascular and metabolic health, not just to assist with weight loss. It should also be noted that cardiorespiratory fitness is inversely associated with the prevalence of metabolic syndrome (28) and those at risk of developing this condition should be encouraged to increase their physical activity from an early age, since poor fitness in young adults is associated with the development of cardiovascular complications (29)

\section{CARDIOVASCULAR RISKS ASSOCIATED WITH OBESITY}

The association between overweight/obesity and CVD risk has been known for many years, with evidence from several large cohort studies (30-32). After 44 years of follow-up of the Framingham Heart Study, Wilson et al (33) showed that risk of CVD (including angina, myocardial infarction, CHD, or stroke) was higher among overweight men (relative risk (RR) 1.24; 95\% confidence interval (CI): 1.07-1.44), obese men (RR 1.38; 95\% CI: 1.12-1.69) and obese women (RR 1.38 ; $95 \%$ CI: 1.14-1.68) after adjustment for age, smoking, high blood pressure, high cholesterol and diabetes. During a 14 year follow up of 1 million adults in the United States, it was found, as BMI increased, that there was an increase in the risk of death from all causes, CVD, cancer or other diseases for both men and women in all age groups (34). These findings confirmed the previous report of the Nurses' Health Study (35). In the Nurses' Health Study, weight gain of 5-8 kg increased CHD risk (non fatal myocardial infarction and CHD death) by $25 \%$, and weight gain of $\geq 20 \mathrm{~kg}$ increased risk more than 2.5 times in comparison with women whose weight was stable within a range of $5 \mathrm{~kg}$ (36). In British men, an increase of 1 BMI unit was associated with a $10 \%$ increase in the rate of coronary events (37).

The Lancet recently published a systematic review of cohort studies assessing the association between body weight, total mortality and CAD (38). This review pooled data from 40 studies which included over 250,000 patients and concluded 
that being overweight or mildly obese gave better outcomes for cardiovascular and total mortality than being in the standard healthy BMI range. Patients with severe obesity (BMI $>35$ $\mathrm{kg} / \mathrm{m}^{2}$ ) had the highest risk for cardiovascular mortality (RR $1.88,95 \%$ CI 1.05-3.34). This outcome suggests that perhaps using percent body fat may be more appropriate than BMI as the indicator of obesity. Another important consideration with this review is that the studies includes only had followup for up to 3-8 years, which is insufficient to detect the full effect of being overweight on $\mathrm{CAD}$ progression and long-term outcomes. It has been suggested that in fact the full effect of obesity on cardiovascular mortality may only be seen after 15 years or more (39). Thompson et al (40) conducted a follow up study in men and reported that the lifetime risk of CHD was significantly higher in severely obese men (BMI of $37.5 \mathrm{~kg} /$ $\mathrm{m}^{2}=46.4 \%$ risk) compared with $34.9 \%$ for lean me of similar age (BMI of $22.5 \mathrm{~kg} / \mathrm{m}^{2}$ ). This risk was substantially reduced with sustained moderate weight loss $(10 \%)$ and would yield substantial health and economic benefits (41).

\section{Degree of adiposity and risk of cardiovascular dis- ease}

Data from 115,886 women in the Nurses' Health Study showed that even mild-to-moderate overweight $(\mathrm{BMI}=25.0-28.9$ $\mathrm{kg} / \mathrm{m}^{2}$ ) increased the risk of nonfatal CHD in middle-aged women after adjustment for age and smoking (RR 1.8; 95\% CI: $1.2-2.5)$. Among those with a BMI $\geq 29 \mathrm{~kg} / \mathrm{m}^{2}$, the risk increased more than 3 folds (RR 3.3; 95\% CI: 2.3-4.5). The effect was substantially reduced after adjusting for other CVD risk factors, but remained significant among those with a BMI $\geq 29 \mathrm{~kg} / \mathrm{m}^{2}$ (RR 1.9; 95\% CI: 1.3-2.6) (42). Willett et al (36) concluded that higher levels of body weight within the "normal' range, as well as modest weight gain (more than $5 \mathrm{~kg}$ ) after 18 years of age, appear to increase risks of CHD in middle-aged women. After controlling for age, smoking, menopausal status, hormone replacement therapy and parental history of CHD, significant increases in risk were still observed among those with a BMI $\geq 23 \mathrm{~kg} / \mathrm{m}^{2}$ compared with those with a BMI $<$ $21 \mathrm{~kg} / \mathrm{m}^{2}$. The RRs for CHD were 1.5 (95\% CI: 1.2-1.8) for a BMI $=23.0-24.9 \mathrm{~kg} / \mathrm{m}^{2}, 2.1$ (95\% CI: $\left.1.7-2.5\right)$ for a BMI $=25.0-28.9 \mathrm{~kg} / \mathrm{m}^{2}$ and $3.6(95 \% \mathrm{CI}: 3.0-4.3)$ for a $\mathrm{BMI} \geq 29$ $\mathrm{kg} / \mathrm{m}^{2}$. However, significant weight gain during adulthood (range: $20-34.9 \mathrm{~kg}$ ) approximately doubled the coronary risk after controlling for initial relative weight level at age 18 years (RR 2.5; 95\% CI: 1.7-3.7). In contrast to weight gain through- out life, 'morbid obesity' (defined as BMI $\geq 40 \mathrm{~kg} / \mathrm{m}^{2}$ ) early in adult life is emerging as a significant risk factor for CHD mortality, the duration of morbid obesity being the strongest predictor of chronic heart failure (CHF) (43).

\section{Method of determining obesity impacts of cardiovascular risk}

There is strong debate as to which anthropometric measure is the best technique to assess the risk of CVD (44-47). Both BMI and waist-hip ratio (WHR) have been found to be independent risk factors for $\mathrm{CHD}$ and mortality irrespective of the presence of other coronary risk factors (44). Waist circumference (48) is strongly correlated with abdominal fat content and is the easiest way to assess a patient's abdominal fat (49). The Health Professionals Follow-up Study found that waist circumference but not BMI predicted risk of death from CVD (50). However, the waist circumference cutoffs lose their incremental predictive power in patients with a $\geq$ BMI $35 \mathrm{~kg} / \mathrm{m}^{2}$ (51). Evidence from the Heart Outcomes Prevention Evaluation (HOPE) study of over 8,000 patients with stable CVD suggests that elevated waist circumference was significantly associated with an increased risk of myocardial infarction (RR 1.23, P $<0.01$ ), heart failure (RR 1.38, $\mathrm{P}<0.03$ ), and total mortality (RR 1.17, $\mathrm{P}<0.05$ ) (52). This supports previous findings from the Framingham Study (53) which reported that the risk of CVD incidence and mortality increased with the degree of regional, central or abdominal obesity. Furthermore, when a group of low-risk, middle aged men were followed over 7.5 years, having a higher waist circumference in association with elevated triglyceride levels increased the risk associated with CVD compared to those with the lowest waist circumference and triglyceride levels (RR 2.13; 95\% CI: 1.21-3.76) (54).

\section{Location of body fat}

In humans and most animal models the development of obesity leads not only to increased fat depots in classical adipose tissue locations but also to significant lipid deposits within and around other tissues and organs, a phenomenon known as ectopic fat storage (55). Cardiac fat depots within and around the heart impair both systolic and diastolic functions, and may in the long-term promote CHF (56). Accumulation of fat around blood vessels (perivascular adipose tissue) may affect vascular function in a paracrine manner, as perivascular adipose tissue cells secrete vascular tone modulating factors, pro-atherogenic cytokines and smooth muscle cell growth 
factors (57). Furthermore, high amounts of perivascular fat could mechanically contribute to the increased vascular stiffness seen after years of obesity (55).

The relative excess of fat in the abdomen aids in the development of diabetes and atherosclerosis (58). The distribution of fat depots in the body is a strong independent predictor of CHD $(52,59,60)$. Indeed, disturbances in lipoprotein metabolism, glucose homeostasis and hypertension have been reported in subjects with an excessive deposition of adipose tissue in the abdomen $(59,61-63)$. In addition, abdominal distribution of body fat is associated with increased plasma levels of fibrinogen and other factors that modulate coagulation, such as plasminogen activator inhibitor-1 (PAI-1) and tissue factor. These same molecules may also contribute to left ventricular dysfunction (64).

\section{STRUCTURAL AND METABOLIC CHANGES IN OBESITY AND IMPACT ON CARDIOVASCULAR RISKS}

Excess adipose tissue results in a number of structural and functional adaptations by the cardiovascular system. With progressive and central accumulations of body fat, many cardiac complications often follow (65). The mechanisms involved are discussed in more detail in the next section.

\section{Cardiovascular structure and function}

Obesity is associated with abnormalities in cardiac structure and function (66-68) which can often be alleviated by weight loss. As there is an increased energy requirement to move excess body weight at any given level of activity, the cardiac workload is greater for obese subjects than for non-obese individuals (68). Thus, obese subjects are known to have higher cardiac output (CO) and a lower total peripheral resistance in the absence of hypertension (23). The high $\mathrm{CO}$ is attributable to increased stroke volume, while heart rate (HR) is usually unchanged (24). The increase in blood volume and $\mathrm{CO}$ in obesity is in proportion to the amount of excess body weight (69). Recent evidence from the HyperGen study shows that both increased total fat mass and fat-free mass are able to cause these physiological changes, although centrally located adipose tissue is particularly strongly associated with increased $\mathrm{CO}$ (70). In moderate to severe cases of obesity, an increased $\mathrm{CO}$ may lead to left ventricular dilatation, increased left ventricular wall stress, compensatory (eccentric) left ventricular hypertrophy (71-73) and left ventricular diastolic dysfunction (74). It is important to emphasize that left ventricular hypertrophy is an important risk factor for CHF.

These complications from obesity occur irrespective of age. It has been reported in children as young as 12 years that obesity impairs the ability to exercise, elevates BP and increases left ventricular mass (LVM), indicating the development of early cardiovascular adaptation/damage in young individuals (75). In fact, the P-DAY Study in young men aged 15 to 34 years demonstrated an accelerated progression of atherosclerosis at autopsy in obese individuals (76). Higher LVM and left ventricular dysfunction have been documented with longer duration of obesity (74). As previously mentioned, weight loss is able to diminish some of these anatomical and pathophysiological adaptations, including increased LVM (77) and abnormal ventricular filling $(78,79)$.

Obesity is associated with changes in the parasympathetic regulation of the heart. This is reflected by impairment of heart rate recovery (HRR) following exercise (80), which is an independent risk factor for CVD and mortality (81). Brinkworth et al (82) investigated HRR in obese men and women free from CVD but with a range of metabolic complications before and after 12 weeks of weight loss. There was a significant improvement in HRR but no change in cardiorespiratory fitness. In this study the improvement in HRR was also associated with a reduction in blood glucose, supporting exercise as an important strategy to improve metabolic pathway regulation.

\section{Metabolic complications}

It has been hypothesized that the insulin resistance associated with obesity may in fact be a protective/adaptive mechanism against further weight gain (83). For many years adipose tissue was considered a passive lipid storage organ. However it is now clear that adipose tissue plays an active role in controlling not only lipid and energy homeostasis but also other biological processes, such as feeding behavior, inflammation, immunity, hemostasis, angiogenesis, and reproduction (84-88). The metabolic alterations of adipose tissue that occur in obesity are numerous. These associate with an increased adipose tissue endo- and paracrine secretion of signal proteins, including growth factors, renin/angiotensin and related molecules, chemokines, and pro- and anti-inflammatory cytokines, collectively named adipokines (84-86).

\section{ADIPOKINES AND CARDIOVASCULAR AND METABOLIC DISEASES}

Today, the list of adipokines include more than 100 proteins 
such as leptin, adiponectin, visfatin, omentin, tumor necrosis factor-alpha (TNF- $\alpha$ ), interleukin-1 (IL-1), IL-6, IL-10, IL-18, IL-1 receptor antagonist, IL-8 and other chemokines as well as transforming growth factor- $\beta 1$ (TGF- $\beta 1$ ), nerve growth factor (NGF) and other growth factors (84-88). The classic cytokines, TNF- $\alpha$ and interleukins, within adipose tissue originate predominantly from in situ macrophages (89-91) and possibly mast cells (84) but also from adipocytes and nonfat cells of the adipose tissue (92). The altered production of these molecules has characterized obesity as a state of chronic, low-grade inflammation (93), which may contribute to the development of insulin resistance and endothelial dysfunction (94-96) and the pathophysiology of CVD (63).

The overproduction of adipokines in obesity contributes to physiological changes in cardiac function. Changes in adipose tissue production of TGF- $\beta 1$ may be a potential pathophysiological mechanism for development of left ventricular filling abnormalities in obesity-associated hypertension (97). A relative deficiency of adiponectin may promote inflammation and vascular dysfunction by a reduced ability to inhibit local proinflammatory signals and prevent plaque formation (98). Proatherogenic chemokines, such as monocyte chemoattractant protein 1 (MCP-1, also named CCL2, cysteine-cysteine motif chemokine ligand 2) and IL-8 (CXCL8), are also elevated in obesity. Such molecules may modulate the migration of granulocytes and monocytes into the arterial wall (57). Increased MCP-1 is associated with a number of alterations in the cardiac system, including increased LVM and altered diastolic filling (99). Persistent inflammation has been associated with CHF by reducing cardiac contractility, inducing cardiac hypertrophy and promoting apoptosis, a process that contributes to undesirable myocardial remodeling (100).

\section{Metabolic syndrome}

The term "metabolic syndrome" refers to a cluster of specific cardiovascular risk factors in one individual, its underlying pathophysiology being insulin resistance (4). Although several sets of diagnostic criteria exist such as those provided by the World Health Organization (101), National Cholesterol Education Program (102), and the International Diabetes Federation (103, 104)), waist circumference, dyslipidemia, elevated blood pressure and glucose intolerance are shared by all. Data from NHANES in 1988-1992 and 1999-2000 revealed that the prevalence of metabolic syndrome in adolescents aged
12-19 years increased from $4.2 \%$ to $6.4 \%$ over a decade (105). Evidence from the DESIR participants in France revealed that, over a 6 year follow up period, a weight gain of greater than $9 \mathrm{~kg}$ was associated with a $21 \%$ incidence of metabolic syndrome (106). For every kilogram gained over the 6 years, the risk of developing metabolic syndrome increased by $22 \%$. Uncertainty about the mechanism of pathogenesis has resulted in a debate to determine whether the metabolic syndrome is indeed a syndrome or an independent CVD risk factor (107). The next section describes the impact of obesity on each of these conditions.

\section{Atherosclerosis and coronary artery disease}

Increased adiposity is associated with greater risk of atherosclerosis, which leads to coronary artery calcification and the development of CHD. Evidence from the Bogalusa Heart Study found that carotid intimal-medial thickness (IMT) at age 35 years was correlated with BMI measured throughout life (108). The Muscatine Study (109) also found that increased adipose tissue in youth was correlated with an increase in coronary artery calcification and that this association was stronger in males. The associations between obesity and the development of atherosclerotic lesions, as evidenced by fatty streaks and/or fibrous plaque lesions, is of particular concern when damage is seen in young adults (110).

A cross-sectional study by Takami et al (111) of 849 Japanese men aged 20-78 years investigated the relationship between body fatness (particularly abdominal fat) and carotid atherosclerosis. They found that general adiposity (as measured by BMI), waist circumference, WHR, abdominal subcutaneous fat and intra-abdominal fat were all correlated with carotid IMT after adjustment for age and smoking habit. Adjustment for BMI eliminated all other associations except the ones with WHR with IMT, suggesting that in this population abdominal fat is not as strongly associated with carotid atherosclerosis as is general body fatness. The Progetto ATENA study is a large (over 5,000 participants) ongoing investigation of the causes of CVD and cancer in Italian females aged 30 to 69 years. Within that study, De Michele et al (112) reported on a sub-sample of 310 women and concluded that BMI and WHR were significant predictors of carotid wall thickness independent of other cardiovascular risk factors (age, BP, lipid abnormalities, and fasting insulin). As BMI increased, IMT increased along with other coronary risk factors, including systolic blood pressure (SBP), diastolic blood pressure (DBP), triglycerides (TG), 
fasting glucose, insulin, and lower high-density lipoprotein (HDL)-cholesterol concentrations.

Obesity may be an independent risk factor for ischemic heart disease. However, numerous studies have been unable to confirm this association because of the short time period of observation. Indeed, the association between obesity and ischemic heart disease seems evident only after 2 decades of follow-up (32). The Manitoba Heart Study reported that a high BMI was significantly associated with development of myocardial infarction, coronary insufficiency and sudden death (32).

\section{Hypertension}

The majority of patients with high BP are overweight and hypertension is about 6 times more frequent in obese than lean subjects (113). This represents an estimated $12 \%$ increased risk for CHD and $24 \%$ increased risk for stroke (51). The association between obesity and hypertension begins in early life. Longitudinal observations of children, adolescents and young adults enrolled in the Bogalusa Heart Study show that obesity persists over time and is linked to the commonly clustered components of metabolic syndrome, including hypertension, hyperinsulinemia/insulin resistance and dyslipidemia, which in turn is associated with the processes leading to CVD (114). The INTERSALT Study, based on more than 10,000 people from 52 centers and 32 countries around the world reported a significant and independent relationship between high BP and increased BMI in more than $90 \%$ of all participants $(89,115)$. Irrespective of age, for every BMI unit increase, there was an associated increase in SBP of $0.91 \mathrm{mmHg}$ for men and a 0.72 $\mathrm{mmHg}$ increase for women. For DBP, this increase was 0.75 $\mathrm{mmHg}$ for men and $0.5 \mathrm{mmHg}$ for women per BMI unit (89, 115). Overall, a 10-kilogram increase in body weight was associated with an elevation of $3.0 \mathrm{mmHg}$ in SBP and a 2.2 $\mathrm{mmHg}$ in DBP (89).

While the association between obesity and hypertension is well recognised, the underlying pathophysiological mechanisms are still poorly understood. The expansion of extracellular volume and increased $\mathrm{CO}$ are characteristic haemodynamic changes that occur with obesity-related hypertension (94). A variety of endocrine, genetic, and metabolic mechanisms have also been linked to the development of obesity hypertension $(63,65,116-118)$. One potential mechanism leading to the development of obesity-induced hypertension may be through leptin-mediated sympatho-activation (119). Recently devel- oped strains of spontaneously hypertensive rats with obesity may be a promising experimental target for further studies on obesity-related hypertension, although this should be done with caution since the original spontaneously hypertensive rat strain were on a different background and hence the type of hypertension these new rats have developed may have a different pathophysiology (120).

The Framingham Heart Study reported that obesity was significantly correlated with increased LVM (121) and it has been shown that a $10 \%$ reduction in weight of obese hypertensive patients not only reduced blood pressure, but also decreased left ventricular wall thickness and LVM (77). There is evidence in both overweight hypertensive and non-hypertensive patients that weight loss produced by lifestyle modifications reduces $\mathrm{BP}$ levels (122). Weight reduction is one of the rare anti-hypertensive strategies that decreases BP in normotensive as well as hypertensive individuals (51). However, this reduction is not always maintained once weight is stable (123) and it has been suggested that the extent to which BP decreases is influenced by several factors, including the duration of hypertension (124) and the composition of the diet (125).

The reduction in BP could also be attributable to (i) reductions in salt intake concomitant with caloric restriction (122) or (ii) reductions in total circulating and cardiopulmonary blood volume, as well as (iii) reductions in sympathetic nervous system activity (97). The reduction in plasma catecholamines and plasma renin activity, which are associated with decreased sympathetic activity, are also probably playing a role $(98,99)$.

\section{Dyslipidemia}

Dyslipidemia (reduced levels of HDL-cholesterol and elevated apolipoprotein B levels and a prevalence of LDL particles) is commonly found in obesity (126) with central adiposity associated with CHD (74). A BMI change of 1 unit is associated with a decrement change in HDL-cholesterol of $1.1 \mathrm{mg} / \mathrm{dl}$ for young adult men and $0.69 \mathrm{mg} / \mathrm{dl}$ for young adult women (2). There is evidence that weight loss achieved by lifestyle modification in overweight individuals is accompanied by a reduction in serum TG and an increase in HDL-cholesterol (86). Weight loss may also contribute to a reduction in serum total cholesterol and LDL-cholesterol levels (87). Moreover, in subjects with type 2 diabetes, aerobic exercise may mediate an improvement in the lipid profiles through fat loss (127-132). 


\section{Type 2 diabetes mellitus}

Several prospective studies in numerous countries have demonstrated an elevated risk of diabetes mellitus as weight increases (75-77). The development of T2DM is associated with weight gain after age 18 years in both men and women, such that the relative risk of diabetes increases by approximately $25 \%$ for each additional unit of BMI over $22 \mathrm{~kg} / \mathrm{m}^{2}$ (133). Moreover cross-sectional and longitudinal studies show that abdominal obesity is a major risk factor for T2DM ( 30 , 102, 116).

There is strong evidence that weight loss reduces blood glucose levels and hemoglobin $\mathrm{A}_{1 \mathrm{c}}$ levels in patients with T2DM. Moreover, in three European cohorts (> 17,000 men) followed for over 20 years, non-diabetic men with higher blood glucose had a significantly higher risk of cardiovascular and CHD death (134). In addition, it has been demonstrated in the Framingham Offspring Cohort that metabolic factors associated with obesity (overall and central) including hypertension, low levels of HDL-cholesterol, increased levels of TG and insulin worsen continuously across the spectrum of glucose tolerance (135). Although BMI increased steadily with increasing glucose intolerance, the association between most other measures of metabolic risk and glycemia were independent of overall obesity and the gradient of increasing risk was similar for non-obese and obese participants (135). Thus, asymptomatic glucose intolerance is not a benign metabolic condition and characteristics associated with the insulin resistance syndrome should be taken seriously. This is further reinforced by the Quebec Cardiovascular Study, where hyperinsulinemia was reported as an independent risk factor for CHD (136).

\section{Non-alcoholic fatty liver disease}

Another metabolic adaptation that occurs with central obesity is non-alcoholic fatty liver disease (NAFLD. In this condition there is an increase in peripheral free fatty acid flux (mainly derived from abdominal visceral fat depots) and de novo lipogenesis in the liver, which results in accumulation of hepatic fat. The occurrence of NAFLD increases with waist girth such that it is present in over $70 \%$ of people with obesity or T2DM (137). In a prospective nested case control study in 2,103 type 2 diabetic patients, Targher et al (138) found that NAFLD was significantly associated with an increased risk of CVD and overall mortality, independent of classical risk factors and only partly explained by the occurrence of metabolic syndrome. Non-alcoholic fatty liver disease is positively associated with thickening of the carotid artery wall in patients with T2DM (139) and also associated with endothelial dysfunction independent of obesity (140). Further, NAFLD is associated with increased levels of proinflammatory cytokines and markers of oxidative stress as seen with many complications of obesity. Musso et al (141) found that the histological severity of NAFLD was inversely correlated with circulating adiponectin levels independent of abdominal obesity and other metabolic syndrome components. The expression of adiponectin and adiponectin receptor II in the liver are also reduced in NAFLD rodent models (142). This supports previous reports that hypoadiponectinemia was closely related to hepatic fat content in diabetic patients (143) and that adiponectin delivery can alleviate steatosis and liver injury in animal models of fatty liver disease. The mechanisms behind adiponectin protection include modulation of TNF- $\alpha$ secretion/activity $(144,145)$, induction of hepatic fatty acid oxidation and inhibition of fatty acid synthesis (146). The question has been raised as to whether NAFLD contributes towards metabolic and cardiovascular complications or whether metabolic syndrome is the instigator of NAFLD.

\section{Obstructive sleep apnea syndrome}

Obstructive sleep apnea syndrome (OSAS) is one of the many respiratory complications associated with obesity. It is defined as repeated episodes of obstructive apnea and hypopnea during sleep in association with altered cardiopulmonary function (147). Evidence is emerging that patients with apneic events that occur during sleep have associated acute and chronic hemodynamic changes during waking time, including elevated sympathetic tone, decreased stroke volume (SV) and $\mathrm{CO}$, increased $\mathrm{HR}$, and changes in circulating hormones that regulate $\mathrm{BP}$, fluid volume, vasoconstriction and vasodilation $(148,149)$. Weight loss is an effective method for reducing the extent of OSAS (150) and associated disruptive symptoms such as habitual snoring and daytime sleepiness (151).

Obstructive sleep apnea syndrome is thought to be both a systemic and local inflammatory condition (152). Inflammatory processes associated with OSAS may contribute to cardiovascular morbidity. Indeed, it is the presence of systemic inflammation, characterized by elevated levels of certain proinflammatory mediators, such as C-reactive protein (153), leptin (154), TNF- $\alpha$, IL-1 $\beta$, IL-6 (66), reactive oxygen species and adhesion molecules, that may predispose people to the development of cardiovascular complications observed in 


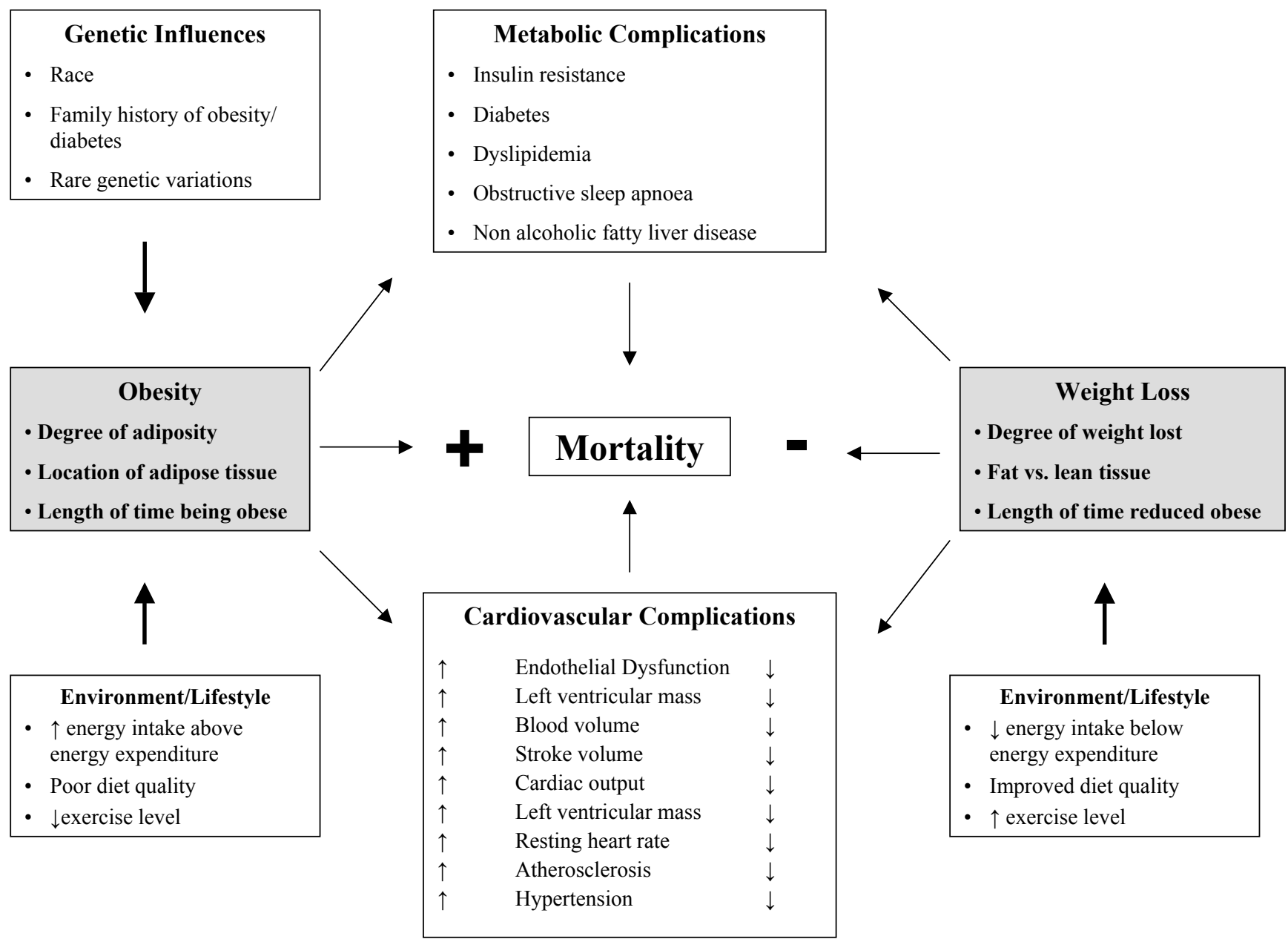

Figure 1. There is a complex interaction between the conditions that cluster to influence risk of cardiovascular disease, obesity appearing to be central to the problem.

patients with OSAS. Interestingly, both TNF- $\alpha$ and IL-6 have been found to be significantly elevated in OSAS independent of obesity (155). To date it is unclear how the cytokines directly mediate OSAS (156).

\section{WEIGHT LOSS: IS IT POSSIBLE TO REVERSE THE DAMAGE?}

In 1998, the American Heart Association added obesity to its list of major modifiable risk factors for CHD (157). Although obesity is modifiable, the prevalence rates continue to increase and weight reduction is difficult to achieve and even harder to maintain, in part due to homeostatic mechanisms protecting against loss of nutrient stores $(158,159)$. Moreover, following weight loss, resumption of the obese state typically occurs, with fewer than $5 \%$ of subjects remaining lean for more than four years (160). Loss of greater than $10 \mathrm{~kg}$ has previously been reported to have multiple benefits (161) but should be done in consultation with a medical professional since it can have cardiovascular complications, depending on the rate of weight loss (65). Incorporating exercise to help achieve weight loss is important to ensure lean mass is preserved (162).

\section{CONCLUSION}

Obesity is a chronic, low-grate inflammatory disorder associated with a number of cardiovascular and metabolic risk factors (163). There are complex paracrine and endocrine communication pathways that in healthy individuals promote homeostasis. However, when challenged in conditions such as obesity, by modulations of genes or environment, these networks can be 
altered in ways that result in deleterious changes to both the cardiovascular system and metabolism that ultimately reduce life span (Fig. 1). It therefore comes as no surprise that CVD is more frequent in subjects with obesity. Moreover, when BMI is $\geq 30 \mathrm{~kg} / \mathrm{m} 2$, mortality rates from all causes, and especially CVD, are increased by 50 to $100 \%$ (68). With an increasing incidence of obesity, it is important that we not only understand the problems associated with excess weight but we strive to identify the underlying molecular mechanisms and ways to prevent further increases. There is strong evidence that weight loss in overweight and obese individuals reduces risk factors for diabetes and CVD. This includes a reduction in deleterious circulating adipokines and a possible increase of beneficial adipokines such as adiponectin, IL-10, and NGF (84 and references therein). Although there have been no prospective trials to convincingly show changes in mortality with weight loss in obese patients, it is anticipated that a reduction in risk factors would predict a reduced incidence of CVD, and perhaps CVD-related mortality. Thus, although the influence of obesity on all cause and CVD-related mortality remains controversial (38), there is a necessary concern for our younger populations with decades of obesity ahead of them.

\section{ACKNOWLEDGMENTS}

The author would like to acknowledge the scientific discussion around this topic with Dr Robert H. Eckel and Dr Paul Poirier.

\section{REFERENCES}

1. WHO. 2000. Obesity: Preventing and Managing the Global Epidemic.World Health Organation. World Health Organisation Technical Report Series (No. 894). Geneva, Switzerland;

2. Bouchard C, Despres JP, Mauriege P. Genetic and nongenetic determinants of regional fat distribution. Endocr Rev 1993; 14: 72-93.

3. Walley AJ, Blakemore AI, Froguel P. Genetics of obesity and the prediction of risk for health. Hum Mol Genet 2006; 15 (Suppl 2): R124-R130.

4. Eckel RH, Grundy SM, Zimmet PZ. The metabolic syndrome. Lancet 2005; 365: 1415-1428.

5. Peeters A, Barendregt JJ, Willekens F, Mackenbach JP, Mamun AA, Bonneux L, et al. Obesity in adulthood and its consequences for life expectancy: A life-table analysis. Ann Intern Med 2003; 138: 24-32.

6. State-specific prevalence of obesity among adults United
States, 2005. MMWR Morb Mortal Wkly Rep 2006; 55: 985-988.

7. Berg C, Rosengren A, Aires N, Lappas G, Toren K, Thelle D, et al. Trends in overweight and obesity from 1985 to 2002 in Goteborg, West Sweden. Int J Obes Relat Metab Disord 2005; 29: 916-924.

8. Zimmet PZ, James WP. The unstoppable Australian obesity and diabetes juggernaut. What should politicians do? Med J Aust 2006; 185: 187-188.

9. Cameron AJ, Welborn TA, Zimmet PZ, Dunstan DW, Owen N, Salmon J, et al. Overweight and obesity in Australia: the 1999-2000 Australian Diabetes, Obesity and Lifestyle Study (AusDiab). Med J Aust 2003; 178: 427-432.

10. Janssen I, Katzmarzyk PT, Boyce WF, Vereecken C, Mulvihill C, Roberts C, et al. Comparison of overweight and obesity prevalence in school-aged youth from 34 countries and their relationships with physical activity and dietary patterns. Obesity Rev 2005; 6: 123-132.

11. Tzotzas T, Krassas GE. Prevalence and trends of obesity in children and adults of South Europe. Pediatr Endocrinol Rev 2004; 1 (Suppl 3): 448-454.

12. Al-Almaie SM. Prevalence of obesity and overweight among Saudi adolescents in Eastern Saudi Arabia. Saudi Med J 2005; 26: 607-611.

13. Kautiainen S, Rimpela A, Vikat A, Virtanen SM. Secular trends in overweight and obesity among Finnish adolescents in 1977-1999. Int J Obes Relat Metab Disord 2002; 26: 544-552.

14. Allison DB, Fontaine KR, Manson JE, Stevens J, VanItallie TB. Annual deaths attributable to obesity in the United States. JAMA 1999; 282: 1530-1538.

15. Flegal KM, Graubard BI, Williamson DF, Gail MH. Excess deaths associated with underweight, overweight, and obesity. JAMA 2005; 293: 1861-1867.

16. Yan LL, Daviglus ML, Liu K, Stamler J, Wang R, Pirzada A, et al. Midlife body mass index and hospitalization and mortality in older age. JAMA 2006; 295: 190-198.

17. Dietz WH. Childhood weight affects adult morbidity and mortality. J Nutr 1998; 128: 411S-414S.

18. Maffeis C, Tato L. Long-term effects of childhood obesity on morbidity and mortality. Horm Res 2001; 55 (Suppl 1): 42-45.

19. Parsons TJ, Power C, Logan S, Summerbell CD. Childhood predictors of adult obesity: a systematic review. Int J Obes Relat Metab Disord 1999; 23 (Suppl 8): S1S107.

20. Weiss R, Dziura J, Burgert TS, Tamborlane WV, Taksali 
SE, Yeckel CW, et al. Obesity and the metabolic syndrome in children and adolescents. N Engl J Med 2004; 350: 2362-2374.

21. Rodriguez BL, Fujimoto WY, Mayer-Davis EJ, Imperatore G, Williams DE, Bell RA, et al. Prevalence of cardiovascular disease risk factors in U.S. children and adolescents with diabetes: The SEARCH for Diabetes in Youth Study. Diabetes Care 2006; 29: 1891-1896.

22. Lurbe E, Alvarez V, Redon J. Obesity, body fat distribution, and ambulatory blood pressure in children and adolescents. J Clin Hypertens (Greenwich) 2001; 3: 362-367.

23. Wright CM, Parker L, Lamont D, Craft AW. Implications of childhood obesity for adult health: findings from thousand families cohort study. BMJ 2001; 323: 1280-1284.

24. Carnethon MR, Gulati M, Greenland P. Prevalence and cardiovascular disease correlates of low cardiorespiratory fitness in adolescents and adults. JAMA 2005; 294: 2981-2988.

25. Li TY, Rana JS, Manson JE, Willett WC, Stampfer MJ, Colditz GA, et al. Obesity as compared with physical activity in predicting risk of coronary heart disease in women. Circulation 2006; 113: 499-506.

26. Lee IM, Rexrode KM, Cook NR, Manson JE, Buring JE. Physical activity and coronary heart disease in women: is "no pain, no gain" passe? JAMA 2001; 285: 14471454.

27. Wessel TR, Arant CB, Olson MB, Johnson BD, Reis SE, Sharaf BL, et al. Relationship of physical fitness vs body mass index with coronary artery disease and cardiovascular events in women. JAMA 2004; 292: 1179-1187.

28. Finley CE, LaMonte MJ, Waslien CI, Barlow CE, Blair $\mathrm{SN}$, Nichaman MZ. Cardiorespiratory fitness, macronutrient intake, and the metabolic syndrome: The Aerobics Center Longitudinal Study. J Am Diet Assoc 2006; 106: 673-679.

29. Carnethon MR, Gidding SS, Nehgme R, Sidney S, Jacobs DR Jr, Liu K. Cardiorespiratory fitness in young adulthood and the development of cardiovascular disease risk factors. JAMA 2003; 290: 3092-3100.

30. Kannel WB, LeBauer EJ, Dawber TR, McNamara PM. Relation of body weight to development of coronary heart disease. The Framingham study. Circulation 1967; 35: 734-744.

31. Hubert HB, Feinleib M, McNamara PM, Castelli WP. Obesity as an independent risk factor for cardiovascular disease: a 26-year follow-up of participants in the Fram- ingham Heart Study. Circulation 1983; 67: 968-977.

32. Rabkin SW, Mathewson FA, Hsu PH. Relation of body weight to development of ischemic heart disease in a cohort of young North American men after a 26 year observation period: the Manitoba Study. Am J Cardiol 1977; 39: 452-458.

33. Wilson PW, D'Agostino RB, Sullivan L, Parise H, Kannel WB. Overweight and obesity as determinants of cardiovascular risk: the Framingham experience. Arch Intern Med 2002; 162: 1867-1872.

34. Calle EE, Thun MJ, Petrelli JM, Rodriguez C, Heath $\mathrm{CW}, \mathrm{Jr}$. Body-mass index and mortality in a prospective cohort of U.S. adults. N Engl J Med 1999; 341: 10971105.

35. Manson JE, Willett WC, Stampfer MJ, Colditz GA, Hunter DJ, Hankinson SE, et al. Body weight and mortality among women. $N$ Engl J Med 1995; 333: 677-685.

36. Willett WC, Manson JE, Stampfer MJ, Colditz GA, Rosner B, Speizer FE, et al. Weight, weight change, and coronary heart disease in women. Risk within the 'normal' weight range. JAMA 1995; 273: 461-465.

37. Shaper AG, Wannamethee SG, Walker M. Body weight: implications for the prevention of coronary heart disease, stroke, and diabetes mellitus in a cohort study of middle aged men. BMJ 1997; 314: 1311-1317.

38. Romero-Corral A, Montori VM, Somers VK, Korinek J, Thomas RJ, Allison TG, et al. Association of bodyweight with total mortality and with cardiovascular events in coronary artery disease: a systematic review of cohort studies. Lancet 2006; 368: 666-678.

39. Dyer AR, Stamler J, Garside DB, Greenland P. Longterm consequences of body mass index for cardiovascular mortality: the Chicago Heart Association Detection Project in Industry study. Ann Epidemiol 2004; 14: 101-108.

40. Thompson D, Edelsberg J, Colditz GA, Bird AP, Oster G. Lifetime health and economic consequences of obesity. Arch Intern Med 1999; 159: 2177-2183.

41. Oster G, Thompson D, Edelsberg J, Bird AP, Colditz GA. Lifetime health and economic benefits of weight loss among obese persons. Am J Public Health 1999; 89: 1536-1542.

42. Manson JE, Colditz GA, Stampfer MJ, Willett WC, Rosner B, Monson RR, et al. A prospective study of obesity and risk of coronary heart disease in women. $N$ Engl J Med 1990; 322: 882-889.

43. Alpert MA, Terry BE, Mulekar M, Cohen MV, Massey CV, Fan TM, et al. Cardiac morphology and left 
ventricular function in normotensive morbidly obese patients with and without congestive heart failure, and effect of weight loss. Am J Cardiol 1997; 80: 736-740.

44. Rao SV, Donahue M, Pi-Sunyer FX, Fuster V. Results of expert meetings: obesity and cardiovascular disease. Obesity as a risk factor in coronary artery disease. $\mathrm{Am}$ Heart J 2001; 142: 1102-1107.

45. Hsieh SD, Yoshinaga H. Abdominal fat distribution and coronary heart disease risk factors in men-waist/height ratio as a simple and useful predictor. Int J Obes Relat Metab Disord 1995; 19: 585-589.

46. Ohrvall M, Berglund L, Vessby B. Sagittal abdominal diameter compared with other anthropometric measurements in relation to cardiovascular risk. Int J Obes Relat Metab Disord 2000; 24: 497-501.

47. Seidell JC, Perusse L, Despres JP, Bouchard C. Waist and hip circumferences have independent and opposite effects on cardiovascular disease risk factors: the Quebec Family Study. Am J Clin Nutr 2001; 74: 315-321.

48. Hu F, Stampfer M, Manson J, Rimm E, Colditz G, Rosner $\mathrm{B}$, et al. Frequent nut consumption and risk of coronary heart disease in women: prospective cohort study. $B M J$ 1998; 317: 1341-1345.

49. Pouliot MC, Despres JP, Lemieux S, Moorjani S, Bouchard C, Tremblay A, et al. Waist circumference and abdominal sagittal diameter: best simple anthropometric indexes of abdominal visceral adipose tissue accumulation and related cardiovascular risk in men and women. Am J Cardiol 1994; 73: 460-468.

50. Baik I, Ascherio A, Rimm EB, Giovannucci E, Spiegelman D, Stampfer MJ, et al. Adiposity and mortality in men. Am J Epidemiol 2000; 152: 264-271.

51. Clinical Guidelines on the Identification, Evaluation, and Treatment of Overweight and Obesity in Adults-The Evidence Report. National Institutes of Health. Obes Res 1998; 6 (Suppl 2): 51S-209S.

52. Dagenais GR, Yi Q, Mann JF, Bosch J, Pogue J, Yusuf S. Prognostic impact of body weight and abdominal obesity in women and men with cardiovascular disease. Am Heart J 2005; 149: 54-60.

53. Kannel WB, Cupples LA, Ramaswami R, Stokes J, 3rd, Kreger BE, Higgins M. Regional obesity and risk of cardiovascular disease; the Framingham Study. J Clin Epidemiol 1991; 44: 183-190.

54. Czernichow S, Bruckert E, Bertrais S, Galan P, Hercberg S, Oppert JM. Hypertriglyceridemic waist and 7.5-year prospective risk of cardiovascular disease in asymptomatic middle-aged men. Int $J$ Obes (Lond) publishd online, 17 October 2006, doi:10.1038/sj.ijo.0803477:

55. Montani JP, Carroll JF, Dwyer TM, Antic V, Yang Z, Dulloo AG. Ectopic fat storage in heart, blood vessels and kidneys in the pathogenesis of cardiovascular diseases. Int J Obes Relat Metab Disord 2004; 28 (Suppl 4): S58-S65.

56. Poirier P, Martin J, Marceau P, Biron S, Marceau S. Impact of bariatric surgery on cardiac structure, function and clinical manifestations in morbid obesity. Expert Rev Cardiovasc Ther 2004; 2: 193-201.

57. Henrichot E, Juge-Aubry CE, Pernin A, Pache JC, Velebit V, Dayer JM, et al. Production of chemokines by perivascular adipose tissue: a role in the pathogenesis of atherosclerosis? Arterioscler Thromb Vasc Biol 2005; 25: 2594-2599.

58. Vague J, Vague P, Tramoni M, Vialettes B, Mercier P. Obesity and diabetes. Acta Diabetol Lat 1980; 17: 87-99.

59. Larsson B, Svardsudd K, Welin L, Wilhelmsen L, Bjorntorp P, Tibblin G. Abdominal adipose tissue distribution, obesity, and risk of cardiovascular disease and death: 13 year follow up of participants in the study of men born in 1913. Br Med J (Clin Res Ed) 1984; 288: 1401-1404.

60. Lapidus L, Bengtsson C, Larsson B, Pennert K, Rybo E, Sjostrom L. Distribution of adipose tissue and risk of cardiovascular disease and death: A 12 year follow up of participants in the population study of women in Gothenburg, Sweden. Br Med J (Clin Res Ed) 1984; 289: 1257-1261.

61. Cigolini M, Targher G, Bergamo Andreis IA, Tonoli M, Agostino G, De Sandre G. Visceral fat accumulation and its relation to plasma hemostatic factors in healthy men. Arterioscler Thromb Vasc Biol 1996; 16: 368-374.

62. Reaven G. All obese individuals are not created equal: insulin resistance is the major determinant of cardiovascular disease in overweight/obese individuals. Diab Vasc Dis Res 2005; 2: 105-112.

63. Poirier P, Lemieux I, Mauriege P, Dewailly E, Blanchet $\mathrm{C}$, Bergeron J, et al. Impact of waist circumference on the relationship between blood pressure and insulin: the Quebec Health Survey. Hypertension 2005; 45: 363367.

64. Licata G, Scaglione R, Avellone G, Ganguzza A, Corrao $\mathrm{S}$, Arnone $\mathrm{S}$, et al. Hemostatic function in young subjects with central obesity: relationship with left ventricular function. Metabolism 1995; 44: 1417-1421.

65. Poirier P, Giles TD, Bray GA, Hong Y, Stern JS, PiSunyer FX, et al. Obesity and cardiovascular disease: pathophysiology, evaluation, and effect of weight loss: 
an update of the 1997 American Heart Association Scientific Statement on Obesity and Heart Disease from the Obesity Committee of the Council on Nutrition, Physical Activity, and Metabolism. Circulation 2006; 113: 898918.

66. Alberti A, Sarchielli P, Gallinella E, Floridi A, Mazzotta G, Gallai V. Plasma cytokine levels in patients with obstructive sleep apnea syndrome: a preliminary study. J Sleep Res 2003; 12: 305-311.

67. Yokoe T, Minoguchi K, Matsuo H, Oda N, Minoguchi $\mathrm{H}$, Yoshino $\mathrm{G}$, et al. Elevated levels of C-reactive protein and interleukin-6 in patients with obstructive sleep apnea syndrome are decreased by nasal continuous positive airway pressure. Circulation 2003; 107: 1129-1134.

68. Poirier P, Despres JP. Exercise in weight management of obesity. Cardiol Clin 2001; 19: 459-470.

69. Alpert MA. Obesity cardiomyopathy: pathophysiology and evolution of the clinical syndrome. Am J Med Sci 2001; 321: 225-236.

70. de Simone G, Devereux RB, Kizer JR, Chinali M, Bella $\mathrm{JN}$, Oberman A, et al. Body composition and fat distribution influence systemic hemodynamics in the absence of obesity: the HyperGEN Study. Am J Clin Nutr 2005; 81: 757-761.

71. Ku CS, Lin SL, Wang DJ, Chang SK, Lee WJ. Left ventricular filling in young normotensive obese adults. Am J Cardiol 1994; 73: 613-615.

72. Hense HW, Gneiting B, Muscholl M, Broeckel U, Kuch B, Doering A, et al. The associations of body size and body composition with left ventricular mass: impacts for indexation in adults. $J$ Am Coll Cardiol 1998; 32: 451-457.

73. Ferrara AL, Vaccaro O, Cardoni O, Panarelli W, Laurenzi $\mathrm{M}$, Zanchetti A. Is there a relationship between left ventricular mass and plasma glucose and lipids independent of body mass index? Results of the Gubbio Study. Nutr Metab Cardiovasc Dis 2003; 13: 126-132.

74. Alpert MA, Lambert CR, Panayiotou H, Terry BE, Cohen MV, Massey CV, et al. Relation of duration of morbid obesity to left ventricular mass, systolic function, and diastolic filling, and effect of weight loss. Am J Cardiol 1995; 76: 1194-1197.

75. Giordano U, Ciampalini P, Turchetta A, Santilli A, Calzolari F, Crino A, et al. Cardiovascular hemodynamics: relationships with insulin resistance in obese children. Pediatr Cardiol 2003; 24: 548-552.

76. McGill HC, Jr., McMahan CA, Herderick EE, Zieske AW, Malcom GT, Tracy RE, et al. Obesity accelerates the progression of coronary atherosclerosis in young men. Circulation 2002; 105: 2712-2718.

77. MacMahon SW, Wilcken DE, Macdonald GJ. The effect of weight reduction on left ventricular mass. A randomized controlled trial in young, overweight hypertensive patients. $N$ Engl J Med 1986; 314: 334-339.

78. Caviezel F, Margonato A, Slaviero G, Bonetti F, Vicedomini G, Cattaneo AG, et al. Early improvement of left ventricular function during caloric restriction in obesity. Int J Obes 1986; 10: 421-426.

79. Alpert MA, Lambert CR, Terry BE, Cohen MV, Mulekar $\mathrm{M}$, Massey CV, et al. Effect of weight loss on left ventricular diastolic filling in morbid obesity. Am J Cardiol 1995; 76: 1198-1201.

80. Lind L, Andren B. Heart rate recovery after exercise is related to the insulin resistance syndrome and heart rate variability in elderly men. Am Heart $J$ 2002; 144 : 666-672.

81. Cole CR, Blackstone EH, Pashkow FJ, Snader CE, Lauer MS. Heart-rate recovery immediately after exercise as a predictor of mortality. N Engl J Med 1999; 341: 13511357.

82. Brinkworth GD, Noakes M, Buckley JD. Clifton PM. Weight loss improves heart rate recovery in overweight and obese men with features of the metabolic syndrome. Am Heart J 2006; 152: 693.e1-693.e6.

83. Eckel RH. Insulin resistance: an adaptation for weight maintenance. Lancet 1992; 340: 1452-1453.

84. Chaldakov GN, Tonchev AB, Tuncel N, Atanassova P, Aloe L. Adipose tissue and mast cells. Adipokines as yin-yang modulators of inflammation. In: Fantuzzi G, Manzzone T, editors. Nutrition and Health. Adipose Tissue and Adipokines in Health and Disease. Humana Press Inc., Totowa, NJ. 2006; 147-154.

85. Fain JN. Release of interleukins and other inflammatory cytokines by human adipose tissue is enhanced in obesity and primarily due to the nonfat cells. Vitam Horm 2006; 74: 443-477.

86. Trayhurn P, Wood IS. Adipokines: inflammation and the pleiotropic role of white adipose tissue. Br J Nutr 2004; 92: 347-355.

87. Fukuhara A, Matsuda M, Nishizawa M, Segawa K, Tanaka M, Kishimoto K, et al. Visfatin: a protein secreted by visceral fat that mimics the effects of insulin. Science 2005; 307: 426-430.

88. Schaffler A, Neumeier M, Herfarth H, Furst A, Scholmerich J, Buchler C. Genomic structure of human omentin, a new adipocytokine expressed in omental adipose tissue. 
Biochim Biophys Acta 2005; 1732: 96-102.

89. Dyer AR, Elliott P. The INTERSALT study: relations of body mass index to blood pressure. INTERSALT Co-operative Research Group. J Hum Hypertens 1989; 3: 299-308.

90. Fain JN, Madan AK, Hiler ML, Cheema P, Bahouth SW. Comparison of the release of adipokines by adipose tissue, adipose tissue matrix, and adipocytes from visceral and subcutaneous abdominal adipose tissues of obese humans. Endocrinology 2004; 145: 2273-2282.

91. Fain JN, Tichansky DS, Madan AK. Transforming growth factor beta 1 release by human adipose tissue is enhanced in obesity. Metabolism 2005; 54: 1546-1551.

92. Sewter CP, Digby JE, Blows F, Prins J, O'Rahilly S. Regulation of tumour necrosis factor-alpha release from human adipose tissue in vitro. J Endocrinol 1999; 163: 33-38.

93. Coppack SW. Pro-inflammatory cytokines and adipose tissue. Proc Nutr Soc 2001; 60: 349-356.

94. Morse SA, Bravo PE, Morse MC, Reisin E. The heart in obesity-hypertension. Expert Rev Cardiovasc Ther 2005; 3: 647-658.

95. Ritchie SA, Ewart MA, Perry CG, Connell JM, Salt IP. The role of insulin and the adipocytokines in regulation of vascular endothelial function. Clin Sci (Lond) 2004; 107: 519-532.

96. Hotamisligil GS, Shargill NS, Spiegelman BM. Adipose expression of tumor necrosis factor-alpha: direct role in obesity-linked insulin resistance. Science 1993; 259: 87-91.

97. Parrinello G, Licata A, Colomba D, Di Chiara T, Argano C, Bologna $\mathrm{P}$, et al. Left ventricular filling abnormalities and obesity-associated hypertension: relationship with overproduction of circulating transforming growth factor beta1. J Hum Hypertens 2005; 19: 543-550.

98. Schondorf T, Maiworm A, Emmison N, Forst T, Pfutzner A. Biological background and role of adiponectin as marker for insulin resistance and cardiovascular risk. Clin Lab 2005; 51: 489-494.

99. Malavazos AE, Cereda E, Morricone L, Coman C, Corsi MM, Ambrosi B. Monocyte chemoattractant protein 1: a possible link between visceral adipose tissue-associated inflammation and subclinical echocardiographic abnormalities in uncomplicated obesity. Eur J Endocrinol 2005; 153: 871-877.

100. Aukrust P, Gullestad L, Ueland T, Damas JK, Yndestad A. Inflammatory and anti-inflammatory cytokines in chronic heart failure: potential therapeutic implications.
Ann Med 2005; 37: 74-85.

101. Alberti KG, Zimmet PZ. Definition, diagnosis and classification of diabetes mellitus and its complications. Part 1: diagnosis and classification of diabetes mellitus provisional report of a WHO consultation. Diabet Med 1998; 15: 539-553.

102. Executive summary of the third report of The National Cholesterol Education Program (NCEP) expert panel on detection, evaluation, and treatment of high blood cholesterol in adults (Adult Treatment Panel III). JAMA 2001; 285: 2486-2497.

103. Alberti KG, Zimmet P, Shaw J. The metabolic syndrome--a new worldwide definition. Lancet 2005; 366: 1059-1062.

104. Alberti KG, Zimmet P, Shaw J. Metabolic syndrome: a new world-wide definition. A Consensus Statement from the International Diabetes Federation. Diabet Med 2006; 23: 469-480.

105. Duncan GE, Li SM, Zhou X-H. Prevalence and trends of a Metabolic Syndrome phenotype among U.S. adolescents, 1999-2000. Diabetes Care 2004; 27: 24382443.

106. Hillier TA, Fagot-Campagna A, Eschwege E, Vol S, Cailleau M, Balkau B, et al. Weight change and changes in the metabolic syndrome as the French population moves towards overweight: The D.E.S.I.R. Cohort. Int J Epidemiol 2006; 35: 190-196.

107. Kahn R, Buse J, Ferrannini E, Stern M. The metabolic syndrome: time for a critical appraisal: joint statement from the American Diabetes Association and the European Association for the Study of Diabetes. Diabetes Care 2005; 28: 2289-2304.

108. Freedman DS, Dietz WH, Tang R, Mensah GA, Bond MG, Urbina EM, et al. The relation of obesity throughout life to carotid intima-media thickness in adulthood: the Bogalusa Heart Study. Int J Obes Relat Metab Disord 2004; 28: 159-166.

109. Davis PH, Dawson JD, Mahoney LT, Lauer RM. Increased carotid intimal-medial thickness and coronary calcification are related in young and middle-aged adults : The Muscatine Study. Circulation 1999; 100: 838842.

110. Berenson GS, Wattigney WA, Tracy RE, Newman WP, 3rd, Srinivasan SR, Webber LS, et al. Atherosclerosis of the aorta and coronary arteries and cardiovascular risk factors in persons aged 6 to 30 years and studied at necropsy (The Bogalusa Heart Study). Am J Cardiol 1992; 70: 851-858. 
111. Takami R, Takeda N, Hayashi M, Sasaki A, Kawachi $\mathrm{S}$, Yoshino K, et al. Body fatness and fat distribution as predictors of metabolic abnormalities and early carotid atherosclerosis. Diabetes Care 2001; 24: 1248-1252.

112. De Michele M, Panico S, Iannuzzi A, Celentano E, Ciardullo AV, Galasso R, et al. Association of obesity and central fat distribution with carotid artery wall thickening in middle-aged women. Stroke 2002; 33: 2923-2928.

113. Stamler R, Stamler J, Riedlinger WF, Algera G, Roberts RH. Weight and blood pressure. Findings in hypertension screening of 1 million Americans. JAMA 1978; 240: 1607-1610.

114. Berenson GS. Obesity-a critical issue in preventive cardiology: the Bogalusa Heart Study. Prev Cardiol 2005; 8: 234-241.

115. Stamler J, Rose G, Elliott P, Dyer A, Marmot M, Kesteloot $\mathrm{H}$, et al. Findings of the International Cooperative INTERSALT Study. Hypertension 1991; 17: 19-15.

116. Poirier P, Despres JP. Waist circumference, visceral obesity, and cardiovascular risk. J Cardiopulm Rehabil 2003; 23: 161-169.

117. Ferrannini E. The haemodynamics of obesity: a theoretical analysis. J Hypertens 1992; 10: 1417-1423.

118. Kozakova M, Fraser AG, Buralli S, Magagna A, Salvetti A, Ferrannini E, et al. Reduced left ventricular functional reserve in hypertensive patients with preserved function at rest. Hypertension 2005; 45: 619-624.

119. Haynes WG. Role of leptin in obesity-related hypertension. Exp Physiol 2005; 90: 683-688.

120. Lerman LO, Chade AR, Sica V, Napoli C. Animal models of hypertension: an overview. J Lab Clin Med 2005; 146: 160-173.

121. Lauer MS, Anderson KM, Kannel WB, Levy D. The impact of obesity on left ventricular mass and geometry. The Framingham Heart Study. JAMA 1991; 266: 231-236.

122. Himeno E, Nishino K, Nakashima Y, Kuroiwa A, Ikeda M. Weight reduction regresses left ventricular mass regardless of blood pressure level in obese subjects. Am Heart J 1996; 131: 313-319.

123. Sjostrom L, Lindroos AK, Peltonen M, Torgerson J, Bouchard C, Carlsson B, et al. Lifestyle, diabetes, and cardiovascular risk factors 10 years after bariatric surgery. $N$ Engl J Med 2004; 351: 2683-2693.

124. Lawrence VJ, Kopelman PG. Medical consequences of obesity. Clin Dermatol 2004; 22: 296-302.

125. Nowson CA, Worsley A, Margerison C, Jorna MK, Godfrey SJ, Booth A. Blood pressure change with weight loss is affected by diet type in men. Am J Clin Nutr 2005;
81: 983-989.

126. Despres JP. Dyslipidaemia and obesity. Baillieres Clin Endocrinol Metab 1994; 8: 629-660.

127. Ross R, Freeman JA, Janssen I. Exercise alone is an effective strategy for reducing obesity and related comorbidities. Exerc Sport Sci Rev 2000; 28: 165-170.

128. Poirier P, Catellier C, Tremblay A, Nadeau A. Role of body fat loss in the exercise-induced improvement of the plasma lipid profile in non-insulin-dependent diabetes mellitus. Metabolism 1996; 45: 1383-1387.

129. Lee S, Kuk JL, Davidson LE, Hudson R, Kilpatrick K, Graham TE, et al. Exercise without weight loss is an effective strategy for obesity reduction in obese individuals with and without Type 2 diabetes. J Appl Physiol 2005; 99: 1220-1225.

130. Lee S, Kuk JL, Katzmarzyk PT, Blair SN, Church TS, Ross R. Cardiorespiratory fitness attenuates metabolic risk independent of abdominal subcutaneous and visceral fat in men. Diabetes Care 2005; 28: 895-901.

131. Ross R, Janssen I, Dawson J, Kungl AM, Kuk JL, Wong $\mathrm{SL}$, et al. Exercise-induced reduction in obesity and insulin resistance in women: a randomized controlled trial. Obes Res 2004; 12: 789-798.

132. Katzmarzyk PT, Church TS, Janssen I, Ross R, Blair SN. Metabolic syndrome, obesity, and mortality: impact of cardiorespiratory fitness. Diabetes Care 2005; 28: 391397.

133. Colditz GA, Willett WC, Rotnitzky A, Manson JE. Weight gain as a risk factor for clinical diabetes mellitus in women. Ann Intern Med 1995; 122: 481-486.

134. Balkau B, Shipley M, Jarrett RJ, Pyorala K, Pyorala M, Forhan A, et al. High blood glucose concentration is a risk factor for mortality in middle-aged nondiabetic men. 20-year follow-up in the Whitehall Study, the Paris Prospective Study, and the Helsinki Policemen Study. Diabetes Care 1998; 21: 360-367.

135. Meigs JB, Nathan DM, Wilson PW, Cupples LA, Singer DE. Metabolic risk factors worsen continuously across the spectrum of nondiabetic glucose tolerance. The Framingham Offspring Study. Ann Intern Med 1998; 128: 524-533.

136. Despres JP, Lamarche B, Mauriege P, Cantin B, Dagenais GR, Moorjani S, et al. Hyperinsulinemia as an independent risk factor for ischemic heart disease. $N$ Engl J Med 1996; 334: 952-957.

137. Targher G, Arcaro G. Non-alcoholic fatty liver disease and increased risk of cardiovascular disease. Atherosclerosis 2007; In Press. 
138. Targher G, Bertolini L, Poli F, Rodella S, Scala L, Tessari R, et al. Nonalcoholic fatty liver disease and risk of future cardiovascular events among type 2 diabetic patients. Diabetes 2005; 54: 3541-3546.

139. Targher G, Bertolini L, Padovani R, Poli F, Scala L, Zenari $\mathrm{L}$, et al. Non-alcoholic fatty liver disease is associated with carotid artery wall thickness in diet-controlled type 2 diabetic patients. J Endocrinol Invest 2006; 29: 55-60.

140. Villanova N, Moscatiello S, Ramilli S, Bugianesi E, Magalotti D, Vanni E, et al. Endothelial dysfunction and cardiovascular risk profile in nonalcoholic fatty liver disease. Hepatology 2005; 42: 473-480.

141. Musso G, Gambino R, Biroli G, Carello M, Faga E, Pacini G, et al. Hypoadiponectinemia predicts the severity of hepatic fibrosis and pancreatic beta-cell dysfunction in nondiabetic nonobese patients with nonalcoholic steatohepatitis. Am J Gastroenterol 2005; 100: 2438-2446.

142. Kaser S, Moschen A, Cayon A, Kaser A, Crespo J, Pons-Romero F, et al. Adiponectin and its receptors in non-alcoholic steatohepatitis. Gut 2005; 54: 117-121.

143. Bajaj M, Suraamornkul S, Piper P, Hardies LJ, Glass L, Cersosimo E, et al. Decreased plasma adiponectin concentrations are closely related to hepatic fat content and hepatic insulin resistance in pioglitazone-treated type 2 diabetic patients. J Clin Endocrinol Metab 2004; 89: 200-206.

144. Xu A, Wang Y, Keshaw H, Xu LY, Lam KS, Cooper GJ. The fat-derived hormone adiponectin alleviates alcoholic and nonalcoholic fatty liver diseases in mice. $J$ Clin Invest 2003; 112: 91-100.

145. Sennello JA, Fayad R, Morris AM, Eckel RH, Asilmaz E, Montez J, et al. Regulation of T cell-mediated hepatic inflammation by adiponectin and leptin. Endocrinology 2005; 146: 2157-2164.

146. You M, Considine RV, Leone TC, Kelly DP, Crabb DW. Role of adiponectin in the protective action of dietary saturated fat against alcoholic fatty liver in mice. Нераtology 2005; 42: 568-577.

147. Strollo PJ, Jr, Rogers RM. Obstructive sleep apnea. $N$ Engl J Med 1996; 334: 99-104.

148. Partinen M, Jamieson A, Guilleminault C. Long-term outcome for obstructive sleep apnea syndrome patients mortality. Chest 1988; 94: 1200-1204.

149. Merritt SL. Sleep-disordered breathing and the association with cardiovascular risk. Prog Cardiovasc Nurs 2004; 19: 19-27.
150. Gami AS, Caples SM,Somers VK. Obesity and obstructive sleep apnea. Endocrinol Metab Clin North Am 2003; 32: 869-894.

151. Bearpark H, Elliott L, Grunstein R, Cullen S, Schneider $\mathrm{H}$, Althaus W, et al. Snoring and sleep apnea. A population study in Australian men. Am J Respir Crit Care Med 1995; 151: 1459-1465.

152. Hatipoglu U, Rubinstein I. Inflammation and obstructive sleep apnea syndrome pathogenesis: a working hypothesis. Respiration 2003; 70: 665-671.

153. Kokturk O, Ciftci TU, Mollarecep E, Ciftci B. Elevated C-reactive protein levels and increased cardiovascular risk in patients with obstructive sleep apnea syndrome. Int Heart J 2005; 46: 801-809.

154. Ulukavak Ciftci T, Kokturk O, Bukan N, Bilgihan A. Leptin and ghrelin levels in patients with obstructive sleep apnea syndrome. Respiration 2005; 72: 395-401.

155. Ciftci TU, Kokturk O, Bukan N, Bilgihan A. The relationship between serum cytokine levels with obesity and obstructive sleep apnea syndrome. Cytokine 2004; 28: 87-91.

156. Vgontzas AN, Bixler EO, Lin HM, Prolo P, Trakada G, Chrousos GP. IL-6 and its circadian secretion in humans. Neuroimmunomodulation 2005; 12: 131-140.

157. Eckel RH, Krauss RM. American Heart Association call to action: obesity as a major risk factor for coronary heart disease. AHA Nutrition Committee. Circulation 1998; 97: 2099-2100.

158. Arch JR. Central regulation of energy balance: inputs, outputs and leptin resistance. Proc Nutr Soc 2005; 64: 39-46.

159. Eckel RH. Obesity: A disease or a physiologic adaptation for survival. In: Eckel, R, editor. Obesity Mechanisms and Clinical Management. Lippincott, Williams and Wilkins, 2003; 3-30.

160. Wing RR, Hill JO. Successful weight loss maintenance. Annu Rev Nutr 2001; 21: 323-341.

161. Campbell I. The obesity epidemic: can we turn the tide? Heart 2003; 89: 22ii-24ii.

162. Stiegler P, Cunliffe A. The role of diet and exercise for the maintenance of fat-free mass and resting metabolic rate during weight loss. Sports Med 2006; 36: 239-262.

163. Morris AM, Poirier P, Eckel RH. Obesity and the heart. In: Fantuzzi G, Mazzone T, editors. Nutrition and Health. Adipose Tissue and Adipokines in Health and Disease. Humana Press Inc., Totowa, NJ. 2006; 313-325. 